\title{
Analysis of the Literature of Financial Stress Index and Proposed Model for Pakistan.
}

\author{
KINZA YOUSFANI \\ Department of Management Sciences, \\ Isra University, Hyderabad Sindh, Pakistan. \\ Email: kinzayousfani@gmail.com \\ Prof. Dr. ABDUL SUBHAN KAZI \\ Department of Management Sciences, \\ Isra University, Hyderabad Sindh, Pakistan. \\ Dr. KARIM BUX SHAH SYED \\ Assistant Professor at IBA, \\ University of Sindh, Jamshoro, Pakistan
}

\begin{abstract}
In the recent past, research in developed markets has aimed at developing various indices that can be applied to apprehend the impact that financial stress can have on a country's economic activity. This article reviews the literature on financial stress and its impact on economic activities. It further presents a proposed methodology for constructing financial stress index and its implications for macroeconomic performance in relation to Pakistan. A review of the literature was conducted discussing (a) the formulation of the financial stress index and (b) its impact on the country's economic activity indicators. The analysis of the literature made it possible to identify the current themes and remaining gaps in the literature on the financial stress index. It is concluded that FSI is beneficial for monitoring and evaluating the usefulness of government economic policies in crisis as well as normal times. Moreover, the index grabs the stresses in the form of financial stress, which is not only from various market sectors but also from their connection through a contagious effect internationally. Therefore, the paper concludes that the FSI could be established and used as an effective tool to measure and monitor financial stress level and its impact on various economic activity indicators in Pakistan.
\end{abstract}

Keywords: Financial Stress Index, GDP, Industrial Production, Foreign Trade, PCA, Emerging Markets, Pakistan.

\section{Introduction}

Financial stress is a phenomenon that is experienced by countries when they undergo any form of financial crisis such as those caused by the banking sector, external debt, and currency crises. The impact of these crises in terms of productivity loss and fiscal costs is very high. According to Laeven and Valencia (2013), financial crises in industrialized nations cost 32 percent of cyclical earnings and 4 percent of GDP, Therefore, policymakers are seeking to avert economic downturns by using a range of tools to track financial stability. One of these tools is the creation of financial stress indexes (FSIs).

Keeping in view the usefulness of FSI as a holistic tool to measure the sensitivity of overall financial instability, it is important to understand the nuts and bolts of this index and its predictive or explanatory power evidenced in the literature. This paper, thus, aims to review the literature on FSI to propose such an Index for Pakistan. The paper further develops a conceptual model for assessing the impact of FSI on key 
economic activities including GDP, industrial production, foreign trade, and gross fixed capital formation. Our paper's main contribution is to review extant literature emphasizing methodological aspects and formulation of FSI and to develop FSI for an emerging economy, Pakistan.

\section{Research Questions}

The article aims to examine and analyze the contemporary literature on the construction of the financial stress index and its impact on economic activities with special reference to Pakistan. The paper addresses the following specific questions.

1. What is the concept and objective of the financial stress index and how it is constructed?

2. How and why is it important to measure the financial stress index for an economy like Pakistan?

3. What are the implications and impact of the financial stress index on the key economic activity variables like GDP, foreign trade, industrial production, and gross fixed capital formation?

\section{Research Objectives}

Based on the research questions above, the following are the main research objectives of the study.

1. The study conducts a review of the literature devoted to the development of the concept of FSI and its construction.

2. The study highlights the importance of measuring the financial stress index for an economy like Pakistan.

3. The study proposes a model to demonstrate the implications and impact of the financial stress index on economic activities particularly GDP, foreign trade, industrial production, and gross fixed capital formation.

The rest of the paper is structured as follows. Section 2 reviews the literature elaborating the concept and objective of FSI alongside methodology used in the construction of the index with its nexus with various economic activity variables. Section 3 deduces a proposed methodology for FSI in Pakistan based on the reviewed literature. Section 4 devises a conceptual model for empirical analysis of the nexus between FSI and key economic activity variables. Section 5 and 6 have the results, and recommendations, and limitations of the study, respectively. Section 7 concludes.

\section{Literature Review}

The following section is based on the review of literature on the development of the financial stress index (FSI). Besides this, the variables which have been used for the development of the financial stress index have also been discussed. These variables have been aimed for the development of the index and additionally, the determinants of economic activity are also reviewed in this part.

\section{The Objective and Concept of FSI}

The general objective of the Financial Stress Index (FSI) is to calculate the overall state of destabilization, i.e., the current threshold of friction, stress, and strain (or lack thereof) in the financial industry, and to summarize it in a single (generally constant) set of data (Holló, 2012). Balakrishnan et al., (2011), elaborates financial stress as a period during which the financial system of a country is strained and unable to perform its fundamental task of intermediation. The author details four defining characteristics of financial instability, which include (a) significant transitions in asset prices, (b) significant spike in risk and/or volatility, (c) liquidity droughts, and (d) issues concerning the overall health of the financial system. Vermeulen et al., (2015) explain that the Financial Stress Index (FSI) is a regular market-based stress analysis of international capital markets. It is based on three stock markets factors, such as differences in 
yields, price metrics, and interest rates. The FSI is positive when the level of stress exceeds normal and negative if the levels of stress are below normal. According to Sinenko et al., 2013, the FSI includes five classifications of metrics: credit, equity valuation, financing, safe assets, and volatility. According to Ferrer et al., (2018), to interpret FSI, the FSI tracks structural financial pressure interruptions in the daily workings of capital markets. Each element in the index evaluates a financial stress attribute. Financial tension can be measured by how factors work together over time. Duprey et al., (2017) further elucidate that a mathematical algorithm detects this correlation and generates a set of vector weights. The significance of the FSI on a specific day is the measured average level of each parameter recorded on the market on that day, comparative to its history. The index is zero when the median is zero, indicating that pressure is at acceptable levels (Cardarelli et al., 2011). The index is measured for each business day in the U.S. Controlling financial stability involves the assessment of both vulnerabilities and stress. The OFR has developed a "Financial System Vulnerabilities Detector" to detect possible flaws in the financial system the inherent shortcomings of a framework that can induce, intensify, or distribute tension (Monin, 2019).

\section{The Factors of Financial Stress Index}

Financial stress indices diverge in their structure (Hakkio \& Keeton, 2009). The following main factors characterize financial stress or tension.

The first is the volatility, which may ascend if increased risk exacerbates investors to respond more firmly to new information. Greater ambiguity can be calculated by tacit or perceived volatility (Nelson \& Katzenstein, 2014).

The second is elevated information asymmetry. Asymmetric information may worsen during an event of crisis or stress if there is a change in the actual quality of lenders or properties, or if knowledge is perceived to be less accurate. Knowledge asymmetries can cause moral hazard and unfavorable selection problems, higher borrowing rates, and lower asset values. Such information could be measured with an increase in credit or funding, or a decrease is perceived in risky asset valuation (Fu et al., 2012).

The third is the lack of willingness to hold risky assets. Georgarakos and Inderst (2014) elucidate that investors who transform their perceptions or tolerance for risk may require more reimbursement for retaining risky assets. These changes can trigger a price decline of risky assets and a rise in the price of safe investments.

The fourth is a lack of willingness to hold illiquid assets. Shareholders may not be willing to hold excess reserves if the demand for liquid assets rises in expectation of unanticipated cash requirements. This may be because of increasing uncertainty or a potential decline in the valuation of properties. The improvement can be calculated by the rise in financing spreads (Green, 2015).

\section{The Construction of financial stress index and its relationship with key economic variables.}

The most recent global economic and financial crisis, which began in mid-2007, underlined the need for systemic risk assessments and prompted a slew of empirical studies. An index can be created in a variety of methods and contain a variety of indicators. Furthermore, according to Kliesen et al., (2012), the financial stress index monitors financial instability by providing a time series of values that suggest an increased risk of a crisis. By delivering changes that help to eliminate information ambiguity, this tool would enable policymakers to detect the drivers of stress in the financial system. On the other hand, the financial stress index also can be used as a supplement to other indicators in determining the soundness of the financial system. This section reviews some of the mainstream literature on the construction and implication of the financial stress index. We arrange the studies in ascending chronological order to help understand the evolution of the FSI as a tool for monitoring economic and financial stability. 
Sinenko et al., (2013) contend that the financial system soundness and economic development have a versatile and close association which emphasizes the significance to constantly evaluate as well as observe the circumstance of a financial system. Therefore, an aggregate effort is made on enhancing the evaluation and monitoring of the tools to generate a system for the efficient reduction and avoidance of systematic risk to keep the financial system stable. Similarly, Balakrishnan et al., (2011) identify five key components for assessing financial stress in emerging markets, including stock market return, banking sector beta, sovereign debt spreads, time-varying stock market return volatility, and an exchange market pressure index. Similarly, Lo Duca and Peltonen (2011) and Hollo, Kremer, and Lo Duca (2012) mentioned the financial stress component as money market, financial intermediaries sector, bond markets, equity markets, and foreign exchange markets. Financial markets factors are generally considered to be components of financial stress, although they are not the only source of financial stress in emerging economies. (Cevik et al., 2016).

Kota (2013) proposes a financial systemic stress index for Albania to capture systemic risk and financial stress in the Albanian economy. The study uses data from various sectors such as the money market, banking sector, foreign exchange rate, and the housing market to develop a common development of stress throughout market segments by incorporating the time-varying correlation method. The method used in the study was based on the portfolio theory by aggregating individual FS indicators. However, the authors measure the interlinkages of different market segments by assessing their impact on economic growth, henceforth, providing a clear method in debating the development of the sub-indices into financial stress. The results of the study mentioned that FSSIA captures the forces in the form of the FS, not only from the different market segments but from their interaction through cross-correlation.

According to Hollo et al., (2011), they developed a composite indicator of systemic stress (CISS) for the Euro Area, which is used to assess the financial system's current state of financial instability. With CISS and industrial production, the author uses a threshold bivariate VAR model. According to the findings, the impact of financial market stress varies depending on the regime, i.e., the impact of financial stress on economic activity in a low-stress regime is negligible, whereas the impact in a high-stress regime significantly reduces economic activity in the month following the shock.

Ekinci (2013) also developed the FSI for Turkey. The index spans the years 2002 to 2013 and provides a summary of stress levels in several areas, including the public sector, capital markets, banking, and foreign currency markets. The study looked at stress in Turkey's financial industry across six years: I high stress (ii) normal stress (iii) global crisis (iv) low stress (v) increasing stress period (vi) decreasing stress period. The author concludes that the public sector is the most important source of stress during times of high stress, the banking sector during times of normal stress, and the capital market and foreign exchange market during times of global crisis. During the low-stress period, the banking sector and capital market were the primary sources of stress relief.

Huotari (2015) also used three optional ways to generate an FSI for the Finnish financial system. The FSIs are monthly indices that measure the state of financial system instability. The 14 distinct stress indicators that make up the Finnish FSI were chosen to offer an aggregate measure of financial stress in the money, bond, foreign currency, and equities markets, as well as the banking sector. To develop the Finnish FSI, the researchers used three commonly used aggregation methods: PCA, variance equal weighting (VEW), and portfolio theoretic accumulation methodology. The study used the PCA and portfolio theoretic approaches to generate FSI, which react to the same known stress events, whereas the variance equal weighting method generates FSI that displays significant stress near the end of the sample, which is difficult to justify. The portfolio theoretic approach, on the other hand, captures the systemic aspect of stress episodes more finely than the PCA. Additionally, the strategy demonstrates a clear distinction between times when the financial system is stable and times when it is unstable. As a result, the portfolio theoretic method has been proven to be the most effective in developing Finnish FSI. 
Ncube et al., (2016) construct FSI for South Africa. The index included the variables that depict various characteristics of the financial sector such as credit stress, NEER volatility, stock volatility, stock spread, Tbill spread, bond spread, and the yield curve. The author used approaches to analyze the stress index as the principal component and a simple equal-weighted. The study examines the link between economic activity by applying a bivariate VAR model. The findings of the study mentioned that financial stress tends to highlight inflationary impacts on numerous types of economic activities. Furthermore, the monetary policy rule's financial stress indicator shows that monetary policy was insufficiently aggressive in responding to stress. Furthermore, by coordinating monetary policy and other policies aimed at financial stability, the financial sector may be relieved of stress while the negative impacts of high FS on the real economy are mitigated. According to the findings, financial stress causes a significant slowdown in a variety of economic activities.

Nagy et al., (2016), on the other hand, demonstrate the importance of financial stress and its consequences on real economic activity. For Romania, the study creates a financial systemic stress index. The equity market, foreign exchange market, banking industry, and government bond market are all included in the FSI. Each sub-index has several stress indicators that each capture more than one typical financial stress symptom. The process of aggregation begins with the individual stress indicators being placed on a common scale. The author uses an empirical cumulative distribution function to transform stress indicators. Using an Exponential weighted moving average approach, the sub-indices are then combined into a composite indicator. According to the study's findings, the financial systemic stress index can help with crisis periodization.

As reported by Raz and Kurniati (2017), the FSI can be used as a complementary indicator in measuring financial system stability. The study computes FSI for the Indonesian financial system using financial market data over the period 2005-2016. The study estimates FSI that consists of a bond and the stock market, and exchange market as its main components. Moreover, the study conducts quantitative and qualitative analyses to check the robustness of the estimated index. The study applied threshold regression and Markov Switching Autoregressive approaches to determine normal and stress periods. Furthermore, the outcome of the study mentioned that FSI can be used as a complementary indicator to measure financial stability.

Abdullah (2017) also used both economic and financial factors to create Malaysian FSI from 1991 to 2015 to investigate the impact of FSI on Malaysian economic activity. The study's goal was to look into the influence of developed FSI as well as forecast MFSI. Stock market volatility, banking sector fragility index, credit stress, money market spread, government bond spread, EMPI, and economic parameters such as 12-month growth rates of trade finance and external debt were all employed in the study. The researchers employed a principal component analysis to calculate the MFSI and asymmetric causality, as well as a structural vector autoregressive to distinguish between causality in good and bad times. The study also looks at structural impulse responses in changes in economic activity as a result of financial stress shocks. However, the analysis suggests that changes in the MFSI have a detrimental impact on Malaysia's economic activities. The shift in economic activities, on the other hand, is positively related to MFSI. Furthermore, asymmetric causality demonstrates that high financial stress affects economic activity during a recession, while economic activity does not affect the MFSI regardless of boom or recession.

Wang et al., (2019) study's findings show that the index is a significant determinant of the movement of China's foreign reserve around its trend. As a result, the study's findings revealed that the importance of domestic financial conditions in explaining China's short-term demand for foreign reserves should be given more consideration.

Stolbov (2019) used a composite index based on a dynamic factor model to accurately capture the dynamics of financial instability in Russia's financial industry. FSI also harms industrial production, energy prices, global and domestic indices of economic policy uncertainty, and geopolitical risk, according to the 
author. Whereas, according to Ekinci (2013), the most significant sources of stress are the public sector at times of high stress, the banking sector during times of normal stress, and the capital and foreign exchange markets during times of global crisis. Through the low-stress period, the banking sector and capital market became the main factors that helped to reduce stress.

Generally, there is a dearth of studies on FSI in Pakistan. However, the global economic and financial persistent crisis of 2008-2009 outcome had given the reason to evaluate the variable financial behavior before outlining any policy and decision making for its implementation. The financial sector of Pakistan has dealt with multiple reforms and contributed effectively to the improvement of its financial market practices. From the last two decades, Pakistan has structured a significant composite indicator for analyzing the stress of the financial market. It has contributed well to capture the financial stress that is majorly arising from the money market, equity market, and exchange market. The financial authorities of Pakistan are monitoring it daily now.

According to the research done by Babar et al., (2019) the banks have complete control over the financial market of Pakistan. Moreover, the analysis of the financial market shows that out of the banking system total assets, almost 44\% of assets are now concentrated in the securities of government until 2015 December. It also shows that $99 \%$ of the debt domestic securities total is recorded which shows the least existence of Pakistan in the market of corporate debt. From the end of FY01 till FY15, the Karachi stock exchange market capitalization got elevated from Rs339 billion to Rs7421 billion. According to these records, efforts have been made for the foreign stress index of Pakistan. The twin deficit issues in the year 2012 had depicted little amount of stress on the financial market (Babar et al., 2019).

In Pakistan, besides the financial risk factors, the political risk role has also been identified as an important disruption reason in the financial market. The significant issues developed because of it includes the weak vision to resolve the debt issues timely, political pressure to structure the un-optimal policies under different governments in the last decades, and public financial poor management (Sadia et al., 2019). Moreover, the manipulation of taxes incorporate has also been observed.

The financial stress of Pakistan has identified political, economic, and financial issues that impact increasing the financial risk factor. Furthermore, the author constructed a monthly financial stress index has been done from 1993- 2016, and the sample period was chosen according to the economy of Pakistan underwent the reforms of finance in 1990. From 2015 to 2016, also the financial market stress stays low as Pakistan got stability macro-economically despite having a weak outlook in front of the world economy (Sadia et al., 2019).

The crisis of finance, the financial stress index that goes above the level of standard deviation shock, that period is considered as highly stressful in comparison to other periods. This index can identify the stress which comes from the money market effectively as it had helped Pakistan to at least make the evaluation process systematic. It is significant to be aware of the financial stress situation. Otherwise, a developing country like Pakistan might fall apart due to a consistent financial and economic crisis. It helps in rectifying the stress shock and helps in focusing on the major improvement areas, which can decrease the stress with time.

Table 1 below summarizes the description of some of the main variables that have been adopted widely in the current literature. 
Table 1: Description of Variables

\begin{tabular}{|c|c|c|}
\hline Variables & Authors & Methods \\
\hline $\begin{array}{l}\text { The riskiness of the } \\
\text { Banking Sector }\end{array}$ & $\begin{array}{l}\text { Kenc, Cevik \& Dibooglu (2020), } \\
\text { Abdullah et al., (2017), Sadia, Bhatti } \\
\text { \& Ahmad (2019), Babar et al., } \\
\text { (2019) }\end{array}$ & $\begin{array}{l}\text { Contingent Claim Analysis (CCA), BSF } \\
\text { index, data on real commercial bank deposit } \\
\text { (CBD), real claims on the domestic private } \\
\text { sector (CDP) } \\
\text { And real foreign liabilities of banks (FLB), } \\
\text { Principal component analysis (PCA), credit } \\
\text { weights, variance-equal approach, simple } \\
\text { CDFs, Capital Asset Pricing Model } \\
\text { (CAPM), Banking Stability Index. }\end{array}$ \\
\hline $\begin{array}{l}\text { Security Market } \\
\text { Risk }\end{array}$ & Kenc, Cevik \& Dibooglu (2020) & $\begin{array}{l}\text { Country beta from the standard CAPM, } \\
\text { asymmetry, and non-normality of returns, } \\
\text { one-factor } \\
\text { Model }\end{array}$ \\
\hline Currency Risk & $\begin{array}{l}\text { Kenc, Cevik \& Dibooglu (2020), } \\
\text { Abdullah et al., (2017), Sadia, Bhatti } \\
\text { \& Ahmad (2019), Park and Mercado } \\
\text { (2013), Balakrishnan et al. (2009) }\end{array}$ & $\begin{array}{l}\text { Exchange Market, Pressure Index, an } \\
\text { average of the exchange rate and foreign } \\
\text { reserve changes, } 12 \text {-month changes in the } \\
\text { exchange rate and total reserves minus gold, } \\
\text { Exchange Market Pressure Index (EMPI), }\end{array}$ \\
\hline External Debt & $\begin{array}{l}\text { Kenc, Cevik \& Dibooglu (2020), } \\
\text { Abdullah et al., (2017), Sadia, Bhatti } \\
\text { \& Ahmad (2019) }\end{array}$ & $\begin{array}{l}\text { The 12-month growth rate of short-term } \\
\text { external debt and total external debt, } \\
\text { external debt using the } 12 \text {-months growth } \\
\text { rate of external liabilities. }\end{array}$ \\
\hline Credit Stress & $\begin{array}{l}\text { Kenc, Cevik \& Dibooglu (2020), } \\
\text { Abdullah et al., (2017), Sadia, Bhatti } \\
\text { \& Ahmad (2019) }\end{array}$ & $\begin{array}{l}\text { The growth rate of the claims in the private } \\
\text { sector. }\end{array}$ \\
\hline $\begin{array}{l}\text { Industrial } \\
\text { Production Index }\end{array}$ & $\begin{array}{l}\text { Kenc, Cevik \& Dibooglu (2020), } \\
\text { Abdullah et al., (2017), Sadia, Bhatti } \\
\text { \& Ahmad (2019) }\end{array}$ & $\begin{array}{l}12 \text { months growth rate of industrial } \\
\text { production index, monthly data on industrial } \\
\text { production, Global Economic Monitor } \\
\text { Database }\end{array}$ \\
\hline Foreign trade & $\begin{array}{l}\text { Kenc, Cevik \& Dibooglu (2020), } \\
\text { Abdullah et al., (2017) }\end{array}$ & 12 months growth rate of foreign trade \\
\hline $\begin{array}{l}\text { Gross Fixed Capital } \\
\text { Investment }\end{array}$ & Kenc, Cevik \& Dibooglu (2020) & $\begin{array}{l}12 \text { months growth rate of gross fixed capital } \\
\text { investment }\end{array}$ \\
\hline
\end{tabular}

\section{Proposed methodology for constructing FSI in Pakistan}

\section{Components of FSI}

Based on the review in the previous section some of the main components that are critically needed while developing a financial stress index for a particular economy are discussed below.

One of the major components of FSI is stock market volatility, which is a quantitative measure of a specific asset's or stock market index's return distribution. In most cases, the higher the level of ambiguity, the higher the danger of security. The standard deviation or the difference in the results of the same sector or stock index are two ways to calculate volatility (Engle et al., 2013). Volatility in financial markets is often synonymous with broad movements in any direction and volatility of a resource is a crucial consideration when it comes to buying options contracts (Gabaix, et al., 2006). 
The second key component is currency risk which is alluded to as exchange rate risk is the probability that currency depreciation may adversely impact the valuation of one's resources, liabilities, and related interest and corporate dividend sources, notably those financial assets denominated in foreign currency (Lustig, and Verdelhan, 2007). Corporations trading in international markets are often subject to currency risk, as their overseas financial statements must be reported in the company's domestic currency. Corporate treasurers and fund managers, in particular for bigger international companies where the risk is real, seek to mitigate this risk using a range of hedge strategies, where possible (Lustig et al., 2014).

The third component used in the development of the FSI is credit stress. By drawing on the literature, it is observed that the development of the financial stress index also involves the consideration of credit stress. This has also been endorsed through the findings of Misina (2018), who have suggested that credit stress is also required to be included in the development of the financial stress index. However, it has also been mentioned by the researcher that credit stress is not measured directly.

The fourth component used in FSI is the external debt which plays a clinical role in the economic growth of developing countries nonetheless, it has also been discussed that excessive increase in external debt also poses threat to the sustainability of external debt. While referring to the findings of Cevik et al., (2013), it has been discussed that short-term external debt was the one underlying reason behind the Asian and Russian crises therefore, it needs to be part of the financial stress index.

The fifth indicator is the banking sector's riskiness is the fifth indicator. According to Cevik et al., (2013), the soundness of the financial system is considered to be crucial, especially for developing nations, when considering sustainable economic development. Therefore, to take this into account, the financial sector's default probability must be calculated.

\section{Applying the principal component analysis to develop the index.}

There are several accumulation methods, comprising of equal weighing method, principal component analysis, regression-based weighing method, goal programming, and portfolio aggregation method, among others (Cardarelli et al., 2011). Principal component analysis (PCA) is a common component that is supposed to capture the stress that is extracted from many variables (Huotari 2015). According to Abdi and Williams (2010), PCA is a dimensional-reduction approach that has been used to decrease the dimensionality of massive data sets by morphing a large number of variables into a shorter one that also includes almost all of the information in a large number.

Specifically, the PCA infer that each of the variables used to create the FSI that apprehends some feature of financial stress. The Financial stress index also represents info on systemic stress which cannot be captured by the individual market stress measures (Huotari 2015). While the variance equal weight technique is the most generally used accumulation method (Illing and Liu 2006, Cevik et al., 2013, Park and Mercado 2014, Malega and Horváth, 2017) it doesn't capture the systemic nature of a stress event in contrast to the PCA (Hakkio and Keeton, 2009). Moreover, the variance equal weight (VEW) technique doesn't include comovement and correlation during diverse stress indicators (Huotari, 2015). This explains the use of Principal component analysis in addition to the VEW in this review study.

One more additional benefit of using the PCA is that it helps in dividing variables with nominal info loss. Therefore, for PCA to be used, there must be an adequate correlation between the variables. So, PCA can be employed for the development of FSI as the most robust method. 


\section{Conceptual framework for the analysis of the nexus between FSI and key economic activity indicators.}

The primary goal of this research is to examine the influence of the financial stress index on the economic activities of Pakistan. Therefore, the two of the most important constructs of this study are the financial stress index and economic activity indicators. The concept of the financial stress index has been comprehensively discussed in the previous section along with some of the key factors of the financial stress index are also identified. In this regard, to ascertain the relationship of the financial stress index on economic activity, it is important to identify the key components and factors that are widely used to measure the variable of economic activity. These indicators are discussed below.

Gross Domestic Product (GDP) is the first dependent variable and one of the most prominent economic factors that are also widely recognized as an important determinant of measuring the economic activity of any country. According to Puglisi and Serban (2019), GDP is defined as the total value of services and goods produced by a country's economy, excluding the value of services and goods consumed in production. Furthermore, gross private domestic investments, personal consumption expenditures, gross investment, and government consumption expenditures, and net exports of goods and services are also considered to be part of GDP. Similarly, according to Chirwa and Odhiambo (2016), GDP can be defined as the entire market and monetary worth of all final goods and services produced within a country's border at a given point in time. Hence, GDP as a comprehensive measure of overall domestic production serves as a comprehensive scorecard of the economic health of a given country. As mentioned in the study of Kamitewoko (2013), GDP is one of the most extensively used measures of the economy's production or output. Moreover, following the same study, GDP is regarded as the most appropriate and accurate indicator of economic size and is probably the best measure of economic growth of any country.

The second important economic activity measure which can be used as a dependent variable is foreign trade that can be simply understood as an exchange of services, goods, and capitals across international territories or international borders (Tah et al., 2019). In most economies, foreign trade represents the major share of a country's GDP. The significance of foreign trade has been well recognized in the existing body of literature, as it promises to make a significant political, social and economic contribution. As mentioned in the study of (Shikhalev et al., 2018), foreign trade opens up opportunities for countries and consumers to expose the services and goods that are not available in their own country, or else those products might be more expensive in the domestic market. The study conducted by $\mathrm{Li}$ et al., (2019), also recognizes the importance of foreign trade and states that it is one of the most important factors for enhancing the living standards of people, generating more employment opportunities, and allowing consumers to make use of a different variety of goods. The different economies around the world have recognized the importance of foreign trade for fostering economic growth, thus it is now commonly regarded as one of the important economic activities. According to Vartale (2020) and Zayniddinov (2020), all countries required the sufficient production of goods and services in a country to meet the people's wants, and this level of production is highly subjected to the availability of resources. This reflects the importance of foreign trade as a major economic activity.

The third activity is industrial production that is defined as the output measure for the industrial, economic sector. It involves the major competent that is the mining, manufacturing, and utilities of a country. The financial sector contributes to the smaller GDP portion, which is highly in demand of customers. The inflation measurement is also done by this factor in which the levels of uncontrolled consumption are measures along with the rapid inflation. Industrial production is a part of the revolution that comes in the industry (Olimov and Khotamov, 2020). This aspect is referred to as the industrial establishment output that is a significant variable of the financial stress index. In Pakistan, its industrial production has been calculated from time to time in any other country as it provides an overview of the active financial situation globally and domestically also. The improvement areas in the financial and economic crisis can be identified through it. It has been linked with the variables of GDP. Normally the Federal Reserve Board 
plans are issues in the industrial production index that is called the annual revision of industrial sector outcome. It is associated with the annual benchmark data manufacturing analysis, which is, in the end, incorporates into the annual data (Khoroshavina et al., 2018). According to the literature search, the researcher has found the industrial production variable a significant part of the financial stress index performed in Pakistan.

The fourth dependent variable is Gross fixed capital formation that is based on the measuring process of the net increase in the fixed type of capital. It focuses on the spending's done on the land betterment, machinery equipment and plant purchase, construction process of railways, commercial buildings, roads, industrial buildings, and private residential dwellings. It is a macroeconomic concept that is a part of official accounts nationally. The Gross fixed capital formation is considered as the expenditure component of gross domestic product (GDP). This variable does not use to measure the total investment. It is only utilized for the value net additions to the measure of fixed assets (Meyer and Sanusi, 2019). In Pakistan, the Gross fixed capital formation has been recorded till the last few years up till 2019 in which the focus was the major improvements and construction performed in this country (Zahir and Rehman, 2019). The following is the diagrammatical representation of the flow of the study and is labeled as a conceptual framework.

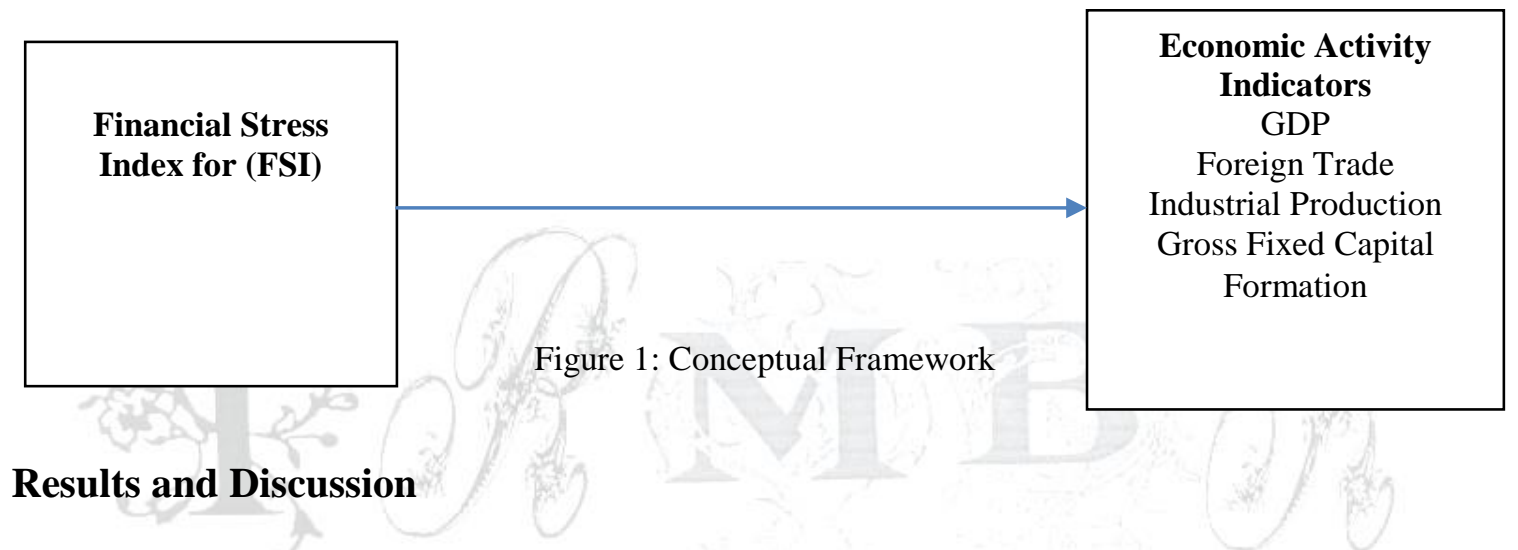

The financial stress that began in the developed economies spread vigorously and hastily to emerging economies. The purpose of the financial indicator is to deliver a rapid, vibrant, and spontaneous valuation of the present circumstances of the financial system. Therefore, we review the literature on the indicators used to develop the financial stress index and its influence on economic activities with various methods. Numerous studies have been reviewed in the paper. The results and findings of some of the major studies are discussed here.

The results from empirical studies show that the FSI is reasonably effective in acting as an important indicator of aggregate economic activities and also useful in capturing recession. The most important components used to develop FSI in the previous studies were the money market, foreign exchange market, bond market spreads, trade finance, stock market volatility, probability of banking sector, external debt. Additionally, it is observed that the authors have applied different methods to obtain a composite index that is an average of the standardized variables. Most of the studies on developed economies have applied principal component analysis to aggregate all variables. Moreover, to specify the measure of economic activity foreign trade, and industrial production were used.

In the light of the presented review literature, it appears that not too many studies have been conducted to measure the financial stress and its implications for economic indicators in Pakistan. This study thus endeavored to propose the model following extant literature to carry out this objective. 


\section{Limitations and Recommendations for Future Research}

Numerous research papers have become available on a financial stress index for the individual as well as multiple countries. However, FSI for an individual country combines more financial stress-related components into one statistic. Not surprisingly, the major limitation in this regard is the non-availability of data. For this reason, most indices do not include some sectors such as the real estate sector, and market securitization; even though there are justifiable reasons for including these sectors of the financial system in creating the index. Further, the index can also be used to analyze the relationship between the financial stress index and economic activity through a variety of statistical methods not used so far.

\section{Summary and Conclusions}

This work reviewed the methodological aspects of the construction of the financial stress index (FSI) to calibrate and measure financial system stress. The motivation for each indicator used to produce the stress index is empirically discovered in this current literature review. We have found that the financial stress index is effective for stress monitoring. The emphasis on financial stress measurement opens up new avenues for future research.

Various methods have been used to develop FSI. Equal market weights, credit weights, portfolio theoretic weights, and principal component analysis (PCA) are among the weighting approaches used to produce FSI. To validate the selection of credit weights, we investigated the literature to determine the evidence quality of each index construction at varied frequencies. Furthermore, the relative quality of information between the growth of FSI and its importance, as well as the dynamic character of the PCA methodology, is compared in the research. PCA method can match the adaptive nature of the financial system to avoid the criticism of arbitrary market selection affected by credit weights.

An elevated level of financial stress, by definition, harms not only the financial system but also causes large losses in the actual economy. A lower level of stress, on the other hand, may cause minor disruptions in the real economy; for example, a tight liquidity situation or asset price instability, either of which might lead to an increase in the cost of capital and a reduction in private consumption and investment. A country-specific financial stress index could be produced and utilized to see its impact on economic activity. FSI has been used to explain variations in real economic variables such as GDP, foreign trade, gross fixed capital formation, and industrial production.

\section{Acknowledgment}

The authors are greatly acknowledging the Senior Faculty member of the Department of Management Sciences; with whom we have had the pleasure to work on this paper. Each of the members has provided extensive professional guidance.

\section{Conflict of Interests}

We hereby state that we are not financially bound to any organization having a direct or indirect financial contribution to achieving the objective of the study.

\section{References}

Abdi, H., \& Williams, L. J. (2010). Principal component analysis. Wiley interdisciplinary reviews: computational statistics, 2(4), 433-459.

Acharya, V. V., \& Ryan, S. G. (2016). Banks' financial reporting and financial system stability. Journal of Accounting Research, 54(2), 277-340. 
Aizenman, J., Lee, J., \& Sushko, V. (2012). From the great moderation to the global crisis: exchange market pressure in the 2000S. Open Economies Review, 23(4), 597-621.

Almahmood, H., Munyif, M. A., \& Willett, T. D. (2018). Most speculative attacks do not succeed: Currency crises and currency crashes. Journal of International Commerce, Economics and Policy, $9(01 \mathrm{n} 02), 1850001$.

Babar, S., Latief, R., Ashraf, S., \& Nawaz, S. (2019). Financial Stability Index for the Financial Sector of Pakistan. Economies, 7(3), 81.

Balakrishnan, R., Danninger, S., Elekdag, S., \& Tytell, I. (2011). The transmission of financial stress from advanced to emerging economies. Emerging Markets Finance and Trade, 47(sup2), 40-68.

Baxa, J., Horváth, R., \& Vašíček, B. (2013). Time-varying monetary-policy rules and financial stress: Does financial instability matter for monetary policy? Journal of Financial Stability, 9(1), 117-138.23.

Cabrera, W., Hurtado, J., Morales, M., \& Rojas, J. S. (2014). A Composite Indicator of Systemic Sress (CISS) for Colombia (Vol. 826). Banco de la República Colombia.

Cardarelli, R., Elekdag, S., \& Lall, S. (2011). Financial stress and economic contractions. Journal of Financial Stability, 7(2), 78-97.

Cevik, E. I., Dibooglu, S., \& Kutan, A. M. (2013). Measuring financial stress in transition economies. Journal of Financial Stability, 9(4), 597-611.

Chirwa, T. G., \& Odhiambo, N. M. (2016). Macroeconomic determinants of economic growth: A review of international literature. southeast European Journal of Economics and Business, 11(2), 33-47.

Cochrane, J. H. (2014). Toward a run-free financial system. Across the great divide: New perspectives on the financial crisis, 197, 214-15.

Duca, M. L., and Peltonen, T. A. (2011). Macro-financial vulnerabilities and future financial stress: assessing systemic risks and predicting systemic events. Working Paper Series 1311, European Central Bank.

Duprey, T., Klaus, B., \& Peltonen, T. (2017). Dating systemic financial stress episodes in the EU countries. Journal of Financial Stability, 32, 30-56.

Ekinci, A. (2013). Financial stress index for Turkey.

Engle, R. F., Ghysels, E., \& Sohn, B. (2013). Stock market volatility and macroeconomic fundamentals. Review of Economics and Statistics, 95(3), 776-797.

Ferrer, R., Jammazi, R., Bolós, V. J., \& Benítez, R. (2018). Interactions between financial stress and economic activity for the US: A time-and frequency-varying analysis using wavelets. Physica A: Statistical Mechanics and its Applications, 492, 446-462.

Fu, R., Kraft, A., \& Zhang, H. (2012). Financial reporting frequency, information asymmetry, and the cost of equity. Journal of Accounting and Economics, 54(2-3), 132-149.

Gabaix, X., Gopikrishnan, P., Plerou, V., \& Stanley, H. E. (2006). Institutional investors and stock market volatility. The Quarterly Journal of Economics, 121(2), 461-504.

Georgarakos, D., \& Inderst, R. (2014). Financial advice and stock market participation. Available at SSRN 1641302.

Green, K. (2015). The illiquidity conundrum: does the illiquidity premium really exist?

Grisse, C., \& Nitschka, T. (2015). On financial risk and the safe haven characteristics of Swiss franc exchange rates. Journal of Empirical Finance, 32, 153-164.

Hakkio, C. S., \& Keeton, W. R. (2009). Financial stress: what is it, how can it be measured, and why does it matter?. Economic Review, 94(2), 5-50.

Holló, D. (2012). A system-wide financial stress indicator for the Hungarian financial system (No. 105). MNB Occasional Papers.

Huotari, J. (2015). Measuring financial stress-A country-specific stress index for Finland. Bank of Finland Research Discussion Paper, (7).

Kamitewoko, E. (2013). Determinants of Economic Activity Choices: Case of Chinese Migrant in Congo Brazzaville. American Journal of Humanities and Social Sciences, 1(4), 228-235.

Kauko, K. (2014). How to foresee banking crises? A survey of the empirical literature. Economic Systems, $38(3), 289-308$. 
Khoroshavina, N. S., Mysachenko, V. I., \& Timofeev, M. I. (2018). State policy in the area of implementation of innovations in industrial production. The Journal of Social Sciences Research, 271276.

Kim, B. Y., \& Park, J. (2016). Financial systems and enterprise restructuring in Eastern Europe. Eastern European Economics, 54(6), 503-520.

Kliesen, K. L., Owyang, M. T., \& Vermann, E. K. (2012). Disentangling diverse measures: A survey of financial stress indexes. Federal Reserve Bank of St. Louis Review, 94(5), 369-397.

Kota, V., \& Saqe, A. (2013). A financial systemic stress index for Albania. In 5th Eastern European Economic Research Workshop" (Tirana, 10-11 November 2011).

Kremer, M., Lo Duca, M., \& Holló, D. (2012). CISS-a composite indicator of systemic stress in the financial system (No. 1426).

Laeven, L., \& Valencia, F. (2013). Systemic banking crises database. IMF Economic Review, 61(2), 225270.

Li, J. (2012). A monetary approach to the exchange market pressure index under capital control. Applied Economics Letters, 19(13), 1305-1309.

Li, N., Sun, L., Luo, X., Kang, R., \& Jia, M. (2019). Foreign Trade Structure, Opening Degree and Economic Growth in Western China. Economies, 7(2), 56.

Lo Duca, M.,\& Peltonen, T. A. (2011). Macro-financial vulnerabilities and future financial stress-Assessing systemic risks and predicting systemic events.

Lustig, H., \& Verdelhan, A. (2007). The cross-section of foreign currency risk premia and consumption growth risk. American Economic Review, 97(1), 89-117.

Lustig, H., Roussanov, N., \& Verdelhan, A. (2014). Countercyclical currency risk premia. Journal of Financial Economics, 111(3), 527-553.

Meyer, D. F., \& Sanusi, K. A. (2019). A Causality Analysis of the Relationships Between Gross Fixed Capital Formation, Economic Growth and Employment in South Africa. Studia Universitatis BabesBolyai Oeconomica, 64(1), 33-44.

Misina, M., \& Tkacz, G. (2018). Credit, asset prices, and financial stress. Nineteenth issue (December 2009) of the International Journal of Central Banking.

Monin, P. J. (2019). The OFR Financial Stress Index. Risks, 7(1), 25.

Nagy, Á., Dézsi-Benyovszki, A., \& Székely, I. (2016). Measuring Financial Systemic Stress In Romania: A Composite Indicator Approach. Financial Studies, 20(3).

Nelson, S. C., \& Katzenstein, P. J. (2014). Uncertainty, risk, and the financial crisis of 2008. International Organization, 361-392.

Oet, M. V., Bianco, T., Gramlich, D., \& Ong, S. J. (2012). Financial stress index: A lens for supervising the financial system. FRB of Cleveland Policy Discussion Paper, (12-37).

Olimov, M., \& Khotamov, I. (2020). Negative impacts of coronavirus pandemic on industrial production in Uzbekistan and measures to overcome. Архив научных исследований, 1(4).

Österholm, P. (2009). The effect on the Swedish real economy of the financial crisis. National Institute of Economic Research, working paper no. 110.

Ozcelebi, O. (2019). Assessment of asymmetric effects on exchange market pressure: Empirical evidence from emerging countries. The North American Journal of Economics and Finance, 48, 498-513.

Puglisi, S., \& Serban, I. V. (2019). Beyond GDP: which options to better represent modern socio-economic progress. Soc. \& Soc. Work Rev., 3, 17.

Raz, A. F. The use of the Financial Stress Index in measuring Indonesia's Financial System Stability.

Sadia, H., Bhatti, A. A., \& Ahmad, E. (2019). Developing a Financial Stress Index for Pakistan. Business and Economic Review, 11(4), 113-131.

Shikhalev, A., Vorontsov, D., Akhmetova, I., Khamidullina, G., \& Rozhko, O. (2018). The foreign economic relations of modern regions: an assessment of trade models potential in economic development in the external restrictions conditions (on the example of the Republic of Tatarstan). In 5th International Multidisciplinary Scientific Conference on social sciences and arts SGEM 2018 (pp. 827-834). 
Sin̨enko, N., Titarenko, D., \& Āriņ̌s, M. (2013). The Latvian financial stress index as an important element of the financial system stability monitoring framework. Baltic Journal of Economics, 13(2), 87-112.

Sözen, A., \& Karık, F. (2017). Comparison of Turkey's renewable energy performance with OECD and BRICS countries by multiple criteria. Energy Sources, Part B: Economics, Planning, and Policy, 12(5), 487-494.

Stolbov, M. (2019). Constructing a Financial Stress Index for Russia: New Approaches. HSE Economic Journal, 23(1), 32-60.

Tah, K. A., Czerniak, C., Levine, A., Wiggin, K., \& Osondu, I. N. (2019). Foreign trade and economic growth in South Africa. Asia-Pacific Journal of Accounting \& Economics, 1-10.

Vartale, M. (2020). Importance of Foreign trade in Economic development.

Vermeulen, R., Hoeberichts, M., Vašíček, B., Žigraiová, D., Šmídková, K., \& de Haan, J. (2015). Financial stress indices and financial crises. Open Economies Review, 26(3), 383-406

Wang, L., \& Hueng, C. J. (2019). Domestic financial instability and foreign reserves accumulation in China. International Finance, 22(2), 124-137.

Watanabe, T. (2012). Quantile forecasts of financial returns using realized GARCH models. The Japanese Economic Review, 63(1), 68-80.

Zahir, S. and Rehman, Z., 2019. Linkage between Gross Fixed Capital Formation, Trade Deficit and Exchange Rate on Economic Growth (Case Study of Pakistan). Journal of Managerial Sciences, 13(4).

Zayniddinov, R. (2020). Socio-economic development with foreign trade (trio of emerging markets, transition economy, and investment attractiveness). Архив научных исследований, (22). 